\title{
Nonlinearity of the Relationship between Human Capital and Exportation in Brazil
}

\author{
Gilberto Joaquim Fraga ${ }^{1}$ and Carlos José Caetano Bacha ${ }^{2}$ \\ ${ }^{1}$ Department of Economics, State University of Maringa, Avenida Colombo, 5.790-UEM, 87020-900 Maringa, PR, Brazil \\ 2 "Luiz de Queiroz" College of Agriculture, University of Sao Paulo, Avenida Padua Dias 11, 13418-900 Piracicaba, SP, Brazil
}

Correspondence should be addressed to Gilberto Joaquim Fraga, gjfraga@uem.br

Received 12 June 2012; Accepted 8 August 2012

Academic Editor: Almas Heshmati

Copyright (C) 2012 G. J. Fraga and C. J. C. Bacha. This is an open access article distributed under the Creative Commons Attribution License, which permits unrestricted use, distribution, and reproduction in any medium, provided the original work is properly cited.

\begin{abstract}
For Brazil to realize the economic benefits of competitive advantage, it is critically important that the country's policy makers have an awareness of the determinants of Brazilian exports. Our study aims to evaluate the role of human capital measured by the average years of workforce formal education, in the value of exports from each Brazilian state from 1995 through 2006 , highlighting differences among the states and/or regions. Based on the Dixit and Woodland (1982) model, our empirical analysis is implemented by running a regression of data organized into a panel that takes into account the fixed effects (i.e., the amenities) found in each of the 27 Brazilian states (including the Federal District). Our findings are consistent with the selected theoretical model and indicate that human capital in Brazil has a nonlinear effect on exportation with an inflection point of 6.7 years of formal education.
\end{abstract}

\section{Introduction}

The increased openness of Brazil to international trade since the 1990s and the consequent growth in trade flows ${ }^{1}$ has attracted the attention of researchers attempting to identify the determinants of international competitiveness in both developing and developed countries. In this context, researchers have focused their attention on specific factors linked with competitiveness, such as the importance of human capital. Several studies have shown a positive relationship between human capital and a country's external competitiveness. Courakis [1]; Maskus, et al. [2]; Cörvers and De Grip [3]; Owen [4]; Chuang [5]; Rodríguez-Clare [6]; Hasnat [7]; Grossman [8]; Brooks [9]; Bougheas and Riezman [10]; Contractor and Mudambi [11]; Jensen [12]; Waugh [13]; Arora and Bagde [14]; Brambilla et al. [15]; Lee and Wang [16] have highlighted the importance of worker education (a proxy for qualification or skill) as a determinant of country's competitiveness in the international market.

Chuang [5] analyzed the relationship between human capital and Taiwanese exportation between 1952 and 1995 and found that there was a positive and stable long-term relationship between the two variables throughout the studied period. Contractor and Mudambi [11] examined two groups of countries to determine the importance of human capital in the evolution of exportation between 1989 and 2003. Their results confirm a positive relationship between the variables for both groups of countries, although this relationship is not linear it suggests an inflection point on the curve relating human capital with exportation. They point out that human capital impacts export value from each region (or country) differently, depending on how developed the region or country is.

Brazil is made up of 27 internally autonomous political units (26 states plus the Federal District) with different geographic dimensions, resources, and populations. In 2009, the country was the world's eighth largest economy. From 1995 to 2006, the value of Brazilian exports grew by an average of $9.75 \%$ annually but this growth was not evenly distributed among Brazilian states. Over that period, the value of exports from the state of Pernambuco grew by an average of $0.39 \%$ annually while the value of exports from the state of Mato Grosso grew by an average of $17.15 \%$ annually. In 1995, Pernambuco held $1.55 \%$ of Brazil's capital 
and $4.51 \%$ of its workforce while Mato Grosso held $0.36 \%$ of the country's capital and $1.54 \%$ of its workforce. At the same year, the average level of human capital measured by years of formal education was 4.41 years in Pernambuco and 5.38 years in Mato Grosso.

The aim of this study is to analyze the impact of human capital on the evolution of Brazilian exportation from 1995 throughout 2006, paying particular attention to the differences among Brazilian states and/or regions. For this purpose, we use a generalization of the Dixit and Woodland [17] model, adding the human capital as a new explanatory variable. The level of human capital is determined by the average number of years of formal education of the share of the workforce employed during each period $t$.

An awareness of the impact of different levels of human capital on exportation should help policy makers when developing strategies intended to increase exportation. For example, trade policies seeking to improve international competitiveness could focus on education to improve worker skill. In a country as large and diverse as Brazil, regional socioeconomic and geographic differences necessitate that training and other educational programs be tailored to fit local conditions.

For our study, we construct an exportable surplus equation starting from a production function in which human capital is added as an explanatory variable. The differences among Brazilian states or regions in their resource endowment will be considered by econometric procedures that estimate the equation using a dataset organized into panels that account for the different fixed effects derived from being located in a particular state. It is hoped that the inclusion of fixed aspects that are not captured in estimates using the standard procedure, such as natural resources, geography, and culture, will lead to a more robust model.

The following relationships are assumed for production factors included in the model: (i) industrial consumption of electricity (proxy for the capital variable) is expected to have a positive relationship with the evolution of exportation; although, the focus of this variable is as a control variable with no highlighted role in the analysis of each state's export trend dynamic; (ii) the workforce, represented by the economically active population, should have a positive relationship with exportation and have a greater impact on exportation than the other factors if the exported products are labor intensive; (iii) the regression coefficient indicating the workforce's average educational level is expected to be positive and nonlinear. The values of estimated coefficients will indicate whether the exported products involve high or low levels of workforce education.

Our study's main contribution will be to determine the importance of human capital to the value of Brazilian exports at the state level, taking into consideration structural changes $^{2}$ in the Brazilian economy and the specific features and characteristics of each Brazilian state. The paper is organized as follows: Section 1, introduction; Section 2, presentation of the theoretical model; Section 3, data and a delineation of econometric procedures; Section 4, the estimated equations and a discussion of results; Section 5, final considerations.

\section{Theoretical Model}

The economic model presented in this section is based on the Dixit and Woodland [17] model, which structures a relationship between the endowment of factors and foreign trade. Dixit and Woodland's model assumes the following initial assumptions: (1) there is identical production technology among the countries (or regions) having constant returns; (2) aggregate preferences are homothetic and identical; (3) there are $n$ inputs (or factors) and $m$ products; (4) productive sectors have a set of production possibilities, represented by $Y(v)$, where $v=\left(v_{1}, \ldots, v_{n}\right)$ is the vector for the endowment of inputs (or factors) and $Y(v)$ is the set of all the technically possible production vectors. Then, it follows that: $Y=\sum_{i=1}^{m} y_{i}$. The production sector maximizes the domestic product, which can be represented by

$$
G(p, v)=\max _{y}\{p \cdot y \mid y \in Y(v)\}, \quad p \geq 0, v \geq 0
$$

where $G(p, v)$ is the production function of the economy, and

$$
G(p, v) \geq 0
$$

where $p=\left(p_{1}, \ldots, p_{m}\right)$ is the price vector of the $m$ products from a small, open, price-taking economy. The function $G(p, v)$ is concave, linearly homogenous, and continuous in $v$ for fixed $p$. Beginning with the assumption that $G$ is differentiable and has constant returns to scale, then, $w_{i}(p, v)=\partial G(p, v) / \partial v_{i}$.

On the consumer's side, there is:

$$
E(p, u)=\min _{c}\{p \cdot c \mid U(c) \geq u\}, \quad p \geq 0, c \geq 0 .
$$

With $E(p, u)$ representing the demand and $E_{u}>0$.

The demand side can be described in terms of expenditure, given a minimum level of utility in accordance with (3), with $U$ being the direct utility function and $c$ is aggregate consumption, with $c=\sum_{i=1}^{m} c_{i}$. The expenditure function is concave, linearly homogenous and continuous in $p$ for a fixed $u$.

By assuming the nonsatiation principle and that all income will be spent, indirect utility can be obtained from solution of the following equation:

$$
S(p, v, u) \equiv G(p, v)-E(p, u)=0,
$$

where $S$ is the indirect utility function.

Solution of (4) generates the maximum possible utility for a given country with an endowment of factor $v$, considering a price level $p$ (what comes from an optimal production system and pattern of trade). Thus, maximum utility can be expressed as

$$
u=J(p, v)
$$

Exports are $x=y-c$ (i.e., exports are the production surplus after domestic consumption) and can be explained as a function of a given price $(p)$ and the endowment of factors 
vector $(v)$ of the country in question. From (4) and (5), the following indirect utility function ${ }^{3}$ of trade arises:

$$
x(p, v)=S[p, v, J(p, v)] .
$$

Consider two nations where factor endowments differ to some extent. Country $A$ has an initial factor endowment equal to $v$, and country $B$ has an initial factor endowment equal to $v^{*}=k v$, where $k$ is a positive scalar. In the view of Hecksher-Ohlin-Samuelson (HOS), this difference allows the endowments' impacts on trade to be a relative function, relative to the amount of a factors used in the production of export goods.

With a determined price ( $p^{0}$ that is given), variations in the value of country $A$ exports can be written as follows

$$
d x^{s}=x_{v} d v .
$$

The equation above establishes that the relationship between the endowment of factors and the international trade of goods is determined by the dependence of $d x^{s}$ in relation to $d v$. Thus, the oversupply $(x)$ of any good $j$ will indicate intensive use of factor $i$ when $\partial x_{j} / \partial v_{i}$ is positive. This effect follows Rybczynski's theorem, which was focused on the production side. ${ }^{4}$

2.1. Model Applied to Brazilian States and Conditioned by Specific Factor Endowments. From the preceding theoretical exposition, it can be concluded that differences among countries (or states) in specific endowments affect these countries' (or states') international trade flows. Our study's empirical specification proposes a general model to examine factors affecting these flows from the 27 Brazilian states (including the Federal District). The model considers each state's physical capital $(K)$, workforce $(L)$, and the educational level of its accumulated human capital $(H)$ in addition to the traditional factors considered by Dixit and Woodland [17]. Assuming that $v=(K, H, L)$ and that the level of production will always be maximized, (7) can be written as:

$$
d X=x_{v} d(K, H, L),
$$

where

$$
x_{v}=\frac{\partial x}{\partial v_{i}} \frac{v_{i}}{x}
$$

Equation (8) states that changes in the value of exports originate from changes in the endowment of factors and can be can be rewritten in linear form as follows:

$$
d X=x_{k} d K+x_{h} d H+x_{L} d L .
$$

Rewriting (10), a country's flow of exports may be written as ${ }^{5}$ :

$$
\begin{gathered}
X_{i t}=\alpha+\beta K_{i t}+\varphi H_{i t}+\phi L_{i t}+u_{i t}, \\
u=\mu_{i}+\eta_{i t},
\end{gathered}
$$

where $X_{i t}$ is the vector of exports from a specific state (or region) to overseas at a certain time $t$; $K$ represents the state's physical capital; $H$ is its human capital, measured by the average educational level of the state's workforce; $L$ is its workforce; $\beta, \varphi$ and $\phi$ are parameters to be estimated; $\mu_{i}$ are unobservable fixed effects; and $\eta_{i t}$ are dynamic shocks.

\section{Data and Econometric Procedures}

3.1. Data. The data used to estimate (11) were obtained from the Brazilian Ministry of Development, Industry and Foreign Trade [18], the Brazilian Institute for Applied Economic Research [19], the Brazilian Ministry of Mining and Energy [20] and the Brazilian Institute of Geography and Statistics [21]. The panel data was composed by 27 Brazilian geographic/political areas (26 states plus the Federal District) and covered a period of 12 years (1995 thru 2006), which created a matrix $N \times T(27 \times 12)$ for each variable in $(11)$. It is worth pointing out that the panel is balanced, that is, the time dimension $(t)$ is not a variable among Brazilian states. The following variables are used in the model:

(1) Exports $(X)$ : the total value of exports from each Brazilian state to overseas measured in thousands of Reais ( $\mathrm{R} \$$ ) deflated by the wholesale price index (IPAOG);

(2) Capital $(K)$ : the industrial consumption of electricity in $\mathrm{MW} /$ hour $^{6}$ for each Brazilian state (this proxy for capital has been used because Brazil does not have information about the stock of physical or investment capital broken down by states);

(3) Human capital $(H)$ : the average number years of formal education of the those employed;

(4) Square human capital $\left(H^{2}\right)$ : the squared value of the former variable;

(5) Workforce $(L)$ : the number of the economically active people (in thousands).

Table 1 shows the change in human capital $(H)$ and the growth rates of exportation $(X)$, capital $(K)$ and workforce $(L)$ for each Brazilian state from 1995 thru 2006. The table's figures mirror regional disparities in Brazil. Over the period, the value of Brazilian exports grew, on average, 9.7\% a year; although, individual state export growth rates showed great spread. The state of Tocantins ${ }^{7}$ registered an export growth rate that averaged $54.2 \%$ annually over the period; whereas, the state of Piauís annual export growth rate averaged a negative 5.1\%/year. Tocantins also registered the highest annual capital $(K)$ growth rate, $9.8 \% / y r$, followed by the state of Rondônia, 9.7\%/yr. Both these states are in the northern part of Brazil. The state of Amapá, also in Brazil's north, showed the lowest annual capital $(K)$ growth rate, $-6.5 \%$ a year. Over the study period, two other northern states, Pará and Roraima, registered the highest annual workforce $(L)$ growth rates, $8.1 \%$ and $7.9 \%$, respectively, while the states of Rio Grande do Sul, in Brazil's south, and Maranhão, in its north, had the lowest annual workforce growth rates.

At the end of our 12 year study period, it was found that improvement in the level of human capital $(H)$, measured by years of worker formal education, has been also extremely differentiated among the states. The greatest increase was in the state of Tocantins and the smallest increase was in the state of Acre. On average, the workforce in Tocantins had approximately 2.5 more years of formal education in 2006 than in 1995, while the formal education of workers in the state of Acre increased only 0.04 year. 
TABLE 1: Exportation, capital, and labor annual percentage growth rates and the increase of human capital (yrs) over the study period (1995 through 2006).

\begin{tabular}{|c|c|c|c|c|c|c|c|c|c|}
\hline \multirow{2}{*}{ State } & \multicolumn{4}{|c|}{ Variables } & \multirow{2}{*}{ State } & \multicolumn{4}{|c|}{ Variables } \\
\hline & $X^{\mathrm{a}}$ & $K^{\mathrm{a}}$ & $L^{\mathrm{a}}$ & $H^{\mathrm{b}}$ & & $X^{\mathrm{a}}$ & $K^{\mathrm{a}}$ & $L^{\mathrm{a}}$ & $H^{\mathrm{b}}$ \\
\hline Acre & 8.85 & 5.24 & 7.35 & 0.04 & Rio Grande do Norte & 10.71 & 5.49 & 1.85 & 1.93 \\
\hline Amazonas & 17.87 & 7.39 & 5.51 & 1.36 & Sergipe & 8.31 & 5.06 & 2.47 & 1.89 \\
\hline Amapá & 3.37 & -6.49 & 5.90 & 1.69 & Distrito Federal & 16.80 & 5.90 & 3.35 & 1.77 \\
\hline Pará & 7.18 & 3.71 & 8.13 & 0.85 & Goiás & 15.58 & 5.79 & 2.49 & 2.25 \\
\hline Rondônia & 15.33 & 9.73 & 6.15 & 0.13 & Mato Grosso do Sul & 7.76 & 6.27 & 2.21 & 1.98 \\
\hline Roraima & 8.88 & 5.06 & 7.86 & 1.06 & Mato Grosso & 17.15 & 9.01 & 2.35 & 1.81 \\
\hline Tocantins & 54.21 & 9.84 & 2.89 & 2.49 & Espírito Santo & 5.28 & 3.63 & 2.32 & 2.05 \\
\hline Alagoas & 1.09 & 0.46 & 1.72 & 1.37 & Minas Gerais & 6.01 & 1.84 & 2.24 & 1.98 \\
\hline Bahia & 8.33 & 3.62 & 1.51 & 2.30 & Rio de Janeiro & 12.15 & -0.21 & 1.85 & 1.50 \\
\hline Ceará & 6.20 & 3.35 & 2.16 & 2.45 & São Paulo & 6.67 & 2.51 & 2.20 & 1.97 \\
\hline Piauí & -5.11 & 7.74 & 1.76 & 1.85 & Paraná & 6.43 & 4.87 & 1.85 & 2.14 \\
\hline Paraíba & 5.23 & 6.49 & 1.59 & 1.56 & Rio Grande do Sul & 4.68 & 5.08 & 1.21 & 1.52 \\
\hline Pernambuco & 0.39 & 2.51 & 1.73 & 2.00 & Santa Catarina & 4.60 & 4.76 & 2.11 & 2.13 \\
\hline Maranhão & 5.63 & 2.08 & 1.29 & 2.14 & & & & & \\
\hline
\end{tabular}

${ }^{\mathrm{a}}$ Annual percentage growth rates of $X, K$, and $L$ were obtained as follows: $X_{2006}=X_{1995} e^{r t}$, where $r$ is the growth rate and $t$ is the time; ${ }^{\mathrm{b}}$ values for human capital $(H)$ represent the change of level of the average for this variable, that is, $H=H_{2006}-H_{1995}$.

3.2. Procedures for Running Regression with Panel Data. Estimations derived from a combination of time series data and cross-sectional data have become increasingly common in economic literature. Baltagi [22] lists some of the advantages that can be gained from using panel data, such as increased responsiveness to individual heterogeneity, more information extraction possibilities, greater variability, less co-linearity among variables, a higher degree of freedom and efficiency, better analysis of adjustment dynamics, and the possibility of identifying and measuring effects that temporal series or pure cross-sectional data alone do not capture.

The regression model for data organized into panels can be represented using the following equation:

$$
X_{i t}=\sum_{j=1}^{k} \beta Z_{i t}^{j}+u_{i t} .
$$

The equation of the error component can be written as

$$
u_{i t}=\mu_{i}+\eta_{i t}
$$

In (13), it is assumed that $\eta_{i t}$ is not correlated with $Z_{i t}$ (a matrix $n \times n$ of explanatory variables). The first term of decomposition $\left(\mu_{i}\right)$, called the individual effect, represents individual state idiosyncrasies. These idiosyncrasies are fixed over time but specific to a particular state, such as the amount of land available for the production of commodities (agricultural and mineral) or whether or not the region lies on the coast.

Equation (12) can be estimated by either of two procedures: random effects modeling or fixed effects modeling. In the random effects model, $\mu_{i}$ is not correlated with $Z_{i t}$. In the fixed effects model, $\mu_{i}$ is correlated with the independent variables $Z_{i t}$, that is, $E\left[\mu_{i} \mid Z_{i t}\right] \neq 0$, and it is assumed that this correlation is constant over time and among the individuals (each Brazilian state). Normally, the two models should be estimated under the conditions of fixed and random effects so that statistical tests can define the most suitable procedure. The test proposed by Hausman [23] verifies whether the fixed and random effect models are identical. If they are, given the condition of orthogonality between the random effects and the independent variables, the best specification is that of random effects. The Maximum Likelihood (ML) test proposed by Breusch and Pagan [24] can be estimated to corroborate the Hausman test results.

\section{Regression Results}

Table 2 presents the estimated parameters of equation (11) resulting from use of both the fixed and random effects procedures. As opposed to the other explanatory variables, human capital was used at a level that enabled direct, relatively easy interpretation. Despite employing neperian logarithm $(\ln )$, the statistical significance remains the same.

These results show that the parameters of both fixed and random effect models are statistically significant. Nevertheless, tests to verify whether the results are linked to heteroskedasticity and autocorrelation phenomena are required as these phenomena are common in regressions using panel data. In principle, the most relevant information in the above regressions comes from the $F$-statistic, which indicates that the fixed effects model is potentially adequate, and from the $22 \%$ correlation between $(\mu+\eta)$ and the independent variables $(Z)$, another indication of the importance of the existing correlation with the states' fixed effects.

The importance of the F-statistic (column 1) is of note. The $F$-statistic shows whether each state has the same longterm export dynamic, that is, $u_{i}=0$, and it was found that 
TABLE 2: Fixed and random effect models-exportation is the dependent variable.

\begin{tabular}{lcc}
\hline $\begin{array}{l}\text { Variables and parameters } \\
(1)\end{array}$ & $\begin{array}{c}\text { Fixed (fe) } \\
(2)\end{array}$ & $\begin{array}{c}\text { Random (re) } \\
(3)\end{array}$ \\
\hline $\ln \mathrm{K}$ & $0.29^{*}$ & $0.35^{*}$ \\
& $(0.09)$ & $(0.09)$ \\
$H$ & $0.30^{*}$ & $0.30^{*}$ \\
& $(0.06)$ & $(0.05)$ \\
$\ln L$ & $1.45^{*}$ & $1.24^{*}$ \\
Constant & $(0.22)$ & $(0.17)$ \\
$R^{2}$ & -14.00 & -11.68 \\
$\operatorname{corr}(\mu+\eta, Z)$ & 0.77 & 0.78 \\
$\sigma_{u=\mu+\eta}$ & 0,22 & - \\
$\sigma_{\eta}$ & 1,09 & 0,93 \\
$F\left[(26.294) \cdot u_{i}=0\right]=36.43$ & Prob $(0.00)$ & 0,53 \\
\hline$N$ & 324 & - \\
\hline
\end{tabular}

Source: estimated by the authors.

*Indicates level of significance equals to $1 \%$; ${ }^{* *}$ indicates level of significance of $5 \%$; ***indicates level of significance of $10 \%$. Values in brackets are the standard deviations. ${ }^{1}$ Estimations done using STATA 10.

each state does. The results show that there are persistent and idiosyncratic differences among Brazilian states, which strengthens the indication that export stimulating economic policies should differ from one state to another. The standard deviation of the fixed effects $\left(\sigma_{\mu}=0.56\right)$ was greater than the standard deviation of the components of imbalance, $\sigma_{\eta}$.

The Hausman [23] specification test is used to determine which model is more suitable. The test can show if the fixed and random effects models are identical or whether they have systematic differences. The Hausman [23] test found a Chisquare of $\chi^{2}=12.52$, which made rejection of the hypothesis of equal coefficients possible, as the likelihood of equality is 0.006 . This level of probability confirms the fixed effects model as the most suitable for this study.

The test suggested by Wooldridge [25] and presented by Drukker [26] is used to check for autocorrelation in panel data. Results of this test show that the $F$ statistic is 10.957 , which indicates that for a significance level of $1 \%$, it is not possible to reject the hypothesis that there is first-order autocorrelation among the regression residuals.

The groupwise heteroskedasticity test (based on the statistic distribution $\chi^{2}$ for the panel data, see Greene [27]) is used to check for the possible presence of heteroskedasticity in the panel groups and verify whether $E\left(u_{i t} u_{j t}\right) \neq I \sigma^{2}$ for $i \neq j$, where $I$ is the identity matrix. The test seeks to verify whether the groups' variances are homoscedastic. The result (Table 3) shows a significance level of $1 \%$; consequently, the hypothesis of heteroskedasticity for the panel group cannot be rejected. Therefore, the data are heteroskedastic, which is compatible with the Brazilian reality.

Considering that the Hausman test may have been influenced by the presence of autocorrelation, we conducted the Maximum Likelihood (ML) test for random effects proposed by Breusch and Pagan [24] and Baltagi and Li [28].
TABLE 3: Tests for random effect and serial correlation.

\begin{tabular}{lcc}
\hline $\begin{array}{l}\text { Tests } \\
(1)\end{array}$ & $\begin{array}{c}\text { Value } \\
(2)\end{array}$ & $\begin{array}{c}\text { Likelihood } H_{0} \\
(3)\end{array}$ \\
\hline Random effects & & \\
$\quad$ ML: $\operatorname{Var}\left(u_{i}\right)=0$ & 28.92 & 0.00 \\
$\quad$ MLA: $\operatorname{Var}\left(u_{i}\right)=0$ & 24.80 & 0.00 \\
Serial correlation & & \\
$\quad$ ML: $\rho=0$ & 237.04 & 0.00 \\
$\quad$ MLA: $\rho=0$ & 15.46 & 0.00 \\
Joint test & & \\
$\quad$ ML: $\operatorname{Var}\left(u_{i}\right)=0$ and $\rho=0$ & 851.87 & 0.00 \\
Heteroskedasticity & & \\
$\quad H_{0}: \sigma_{i}^{2}=\sigma^{2}$ for all $i$ & 8003.9 & 0.00 \\
\hline Source: estimated by the authors. & &
\end{tabular}

This test takes into account the presence of autocorrelation, and its results can be used to make more robust the results from the Hausman test. The results from the ML test are shown in Table 3.

The random effects tests, both the maximum likelihood test without correction for autocorrelation (ML) and the maximum likelihood test that corrects for autocorrelation (MLA), show that the fixed effects model should be chosen given the zero likelihood of random effects. As for serial autocorrelation, the probability of $\rho=0$ is null; therefore, the null hypothesis of nonautocorrelation is rejected by both the ML and MLA tests. The joint test, which checks for the presence of the random effect and the absence of autocorrelation, also showed no statistically significant result.

Up to this point, the results of all tests show that a fixed effects model should be applied, taking into consideration (and correcting for) the presence of autocorrelation and heteroskedasticity. The tests have indicated that the parameters from the first estimates (Table 2) could be biased and that (11) may not be the most suitable. Therefore, the following equation is proposed to discern a nonlinear relationship among human capital and exports, such as the one found by Contractor and Mudambi [11]:

$$
X_{i t}=\alpha+\beta K_{i t}+\varphi H_{i t}+\theta H_{i t}^{2}+\phi L_{i t}+u_{i t} .
$$

The above equation is an extension of (11) with the addition of the square of human ${ }^{8}$ capital as another explanatory variable. The nonlinear inclusion of this variable specifically seeks to capture the impacts of different levels of human capital and to find a potential point of inflection between a level of human capital and exportation.

Four dummy variables were also added to (14) to capture differences among the Brazilian regions and determine the effect of regional location on export performance. The 26 Brazilian states plus the Federal District were grouped into five geographic regions: north, northeast, central-west, southeast and south, with the southeast being the most developed. The dummies represent each region other than the Southeast. 
TABLE 4: Results of regressions run using P-W, FGLS, and GMM Models, the dependent variable is exportation (lnX).

\begin{tabular}{|c|c|c|c|c|c|}
\hline \multirow{2}{*}{$\begin{array}{l}\text { Variables } \\
\text { (1) }\end{array}$} & \multicolumn{2}{|c|}{$\mathrm{P}-\mathrm{W}$} & \multicolumn{2}{|c|}{ FGLS } & \multirow{2}{*}{$\begin{array}{l}\text { GMM } \\
(6)^{\mathrm{a}}\end{array}$} \\
\hline & (2) & (3) & (4) & (5) & \\
\hline \multirow{2}{*}{$\ln X_{t-1}$} & & & & & $0.82^{*}$ \\
\hline & & & & & $(0,07)$ \\
\hline \multirow{2}{*}{$\ln K$} & $0.54^{*}$ & $0.53^{*}$ & $0.43^{*}$ & $0.46^{*}$ & $0.13^{\mathrm{ns}}$ \\
\hline & $(0.08)$ & $(0.09)$ & $(0.06)$ & $(0.05)$ & $(0.11)$ \\
\hline \multirow{2}{*}{$H$} & $1.54^{*}$ & $0.96^{*}$ & $0.964^{*}$ & $0.41^{* * *}$ & $0.76^{* *}$ \\
\hline & $(0.40)$ & $(0.37)$ & $(0.24)$ & $(0.23)$ & $(0.30)$ \\
\hline \multirow{2}{*}{$H^{2}$} & $-0.11^{*}$ & $-0.07^{* *}$ & $-0.064^{*}$ & $-0.03 * * *$ & $-0.057^{* *}$ \\
\hline & $(0.04)$ & $(0.03)$ & $(0.02)$ & $(0.02)$ & $(0.02)$ \\
\hline \multirow{2}{*}{$\ln L$} & $0.87^{*}$ & $1.04^{*}$ & $0.96^{*}$ & $1.18^{*}$ & $0.22^{* * *}$ \\
\hline & $(0.13)$ & $(0.19)$ & $(0.09)$ & $(0.11)$ & $(0.13)$ \\
\hline \multirow{2}{*}{ Central West } & & $-0.26^{\mathrm{ns}}$ & & $0.16^{\mathrm{ns}}$ & \\
\hline & & $(0.38)$ & & $(0.29)$ & \\
\hline \multirow{2}{*}{ Northeast } & & $-0.02^{\mathrm{ns}}$ & & $-0.20^{\mathrm{ns}}$ & \\
\hline & & $(0.45)$ & & $(0.22)$ & \\
\hline \multirow{2}{*}{ North } & & $1.01^{*}$ & & $1.19^{*}$ & \\
\hline & & $(0.46)$ & & $(0.27)$ & \\
\hline \multirow{2}{*}{ South } & & $0.85^{*}$ & & $0.91^{*}$ & \\
\hline & & $(0.29)$ & & $(0.19)$ & \\
\hline Constant & $-12.29 *$ & $-13.12^{*}$ & $-10.32 *$ & $-12.18^{*}$ & $-5.10^{*}$ \\
\hline$R^{2}$ & 0.95 & 0.96 & & & \\
\hline $\operatorname{AR}(2)$ (2nd order serial correlation, $P$ value) & & & & & 0.69 \\
\hline Sargan test & & & & & 0.74 \\
\hline$H^{*}$ (inflection point $)^{\mathrm{b}}$ & 7.0 & 6.9 & 7.5 & 6.8 & 6.7 \\
\hline Number of observations & 324 & 324 & 324 & 324 & 297 \\
\hline
\end{tabular}

Source: estimated by the authors.

*Indicates level of significance of $1 \%$; **indicates level of significance of $5 \%$; *** indicates level of significance of under 10\%, ns: nonsignificant. Robust std error are in parentheses; ${ }^{\mathrm{a}}$ Time dummies are not reported; ${ }^{\mathrm{b}}$ see endnote number 12.

Equation (14) was first run using both the Prais-Winsten $(\mathrm{P}-\mathrm{W})$ and the Feasible Generalized Least Square (FGLS) ${ }^{9}$ methods, because they take into account problems of heteroskedasticity and autocorrelation. Due to that, the same equation was also run using the lagged dependent variable as an explanatory variable and employing the dynamic system GMM $^{10}$ estimator, what eliminates endogeneity or reverse causality among the variables [29]. In order to provide consistent estimates, instrumental ${ }^{11}$ variable is employed, using the dependent and independent lagged variables as instruments. The resulting estimates, shown in Table 4, were statistically significant and robust.

Other estimates were also run grouping the Brazilian states in two groups: (1) more industrialized and (2) less industrialized states (see Table 5 in the appendix). However, the new equations employing GMM are not better than the ones showed in Table 4, especially due to the signal of capital variable for more industrialized states and the signal of workforce for less industrialized states.

Despite three different econometric procedures have been employed in Table 4 (P-W, FGLS, and GMM) and new variables have been added ( $H^{2}$ and regional dummies), the parameters of the variables of key interest have kept the expected signals and they are statistically significant. Thus, the results shown in Table 4 are more robust than those from the basic model shown in Table 2 .

The coefficient of the $\ln K$ variable, which represents industrial consumption of electricity (MW/hour) and acts as a proxy for capital, had a positive and statistically significant signal (except in the dynamic estimates). Although the main function of this proxy is as a control variable in the empirical model, the expected positive relationship between $\ln K$ and exportation was confirmed.

The average years of education variable $(H)$ and its squared value $\left(H^{2}\right)$ should be analyzed together. In accordance with all regressions shown in Table 4, education's contribution to export growth is not linear, with the positive marginal effect of additional workforce education on export value up to a certain point, after which that marginal effect turn negative, assuming a static product mix. The statistical significances of the coefficients associated with $H$ and $H^{2}$ confirm the existence of a quadratic behavior, which will be examined below.

It is expected that the higher the value of the workforce variable $(\ln L)$, the more positive the effect on the value of exports. The results from the estimated models, shown 
in Table 4, give credence to this expectation, and the magnitudes of the parameters from the static models suggest that exports are labor intensive.

The four dummy variables representing four of the five Brazilian geographic regions were included to evaluate regional differences in the structure of the country's export economy. If the sign of the coefficient of any of these dummies is positive and statistically significant, exportation is increasing at a more accelerated pace in that region's states than in the southeast region's states, which are not represented by a dummy. The sign of the coefficients of the dummies representing states located in Brazil's South and North regions is both positive and significant. The coefficients of dummies representing the central-west and northeast are not statistically significant, suggesting that export growth in these regions tends to be similar to export growth in the southwest region states. Given this heterogeneity among Brazilian regions, policies intended to stimulate exports would have a better chance of success if they take regional differentiation into account.

The statistical significance of the human capital variable's coefficient demonstrates the variable's influence on exports. Regressions on columns (3), (5) and (6) in Table 4 show that human capital has a positive effect on exportation, even though this effect has a limit (maximum point). One can see that after a certain human capital level is reached, the coefficient, although small, becomes negative and remains statistically significant. In other words, if the level of education in a determined state is low and increases, it leads to increased exports; however, when the level of education reaches a certain point, improved schooling does not mean increased exports. This result is in agreement with the theoretical assumptions underlying the function of indirect utility of exports ((4) thru (6)). The direct quadratic relationship between exports and the level of human capital may be expressed as $X=\beta_{1} H-\beta_{2} H^{2}$.

Using the parameter values shown in regression (7), see Table 4 , and calculating the partial derivative $(\partial X / \partial H)$ if the final value is zero, the maximum point of the human capital $\left(H^{*}\right)$ is found to be 6.7 years of formal education. ${ }^{12}$ In other words, it was found that the basket of Brazilian exports can be most efficiently produced by workers with approximately seven years of formal education. Looking at Table 4, very close values of $H^{*}$ was founded by using the other possible econometrics model. A little higher value is founded when separating Brazilian states into more and less industrialized states (see Table 5 in the appendix), however, they still are around of 7 years of formal education.

$H^{*}$ equal to 6.7 years of formal education also gives an indication of the level of technology employed in the production of the majority of Brazilian exports. From this data, one can reasonably conclude that policy makers working in states whose workforce averages less than 6.7 years of formal education and intent on improving their state's competitive position by more efficiently producing its current basket of export products would be wise to ensure that members of the workforce have more formal education, both for the industrialized states as for ones less industrialized. As a national policy, a move to the right of
TABLE 5: Results of regressions run by using GMM models, the dependent variable is exports $(\ln X)$, but separating Brazilian states into more and less industrialized states.

\begin{tabular}{lcc}
\hline \multirow{2}{*}{ Variables } & \multicolumn{2}{c}{ GMM } \\
& More industrialized & Less industrialized \\
& states & states \\
\hline $\ln X_{t-1}$ & $0.879^{*}$ & $(2)$ \\
& $(0.079)$ & $0.895^{*}$ \\
$\ln L$ & $0.249^{*}$ & $(0.106)$ \\
& $(0.075)$ & -0.123 \\
$H$ & $0.928^{* *}$ & $(0.208)$ \\
& $(0.424)$ & $0.628^{*}$ \\
$H^{2}$ & $-0.0604^{* *}$ & $(0.217)$ \\
& $(0.029)$ & $-0.0432^{*}$ \\
$\ln K$ & $-0.162^{* *}$ & $(0.016)$ \\
& $(0.072)$ & $0.270^{* * *}$ \\
Constant & $-2.825^{* *}$ & $(0.158)$ \\
AR(2) (2nd-order serial & $(1.299)$ & -2.726 \\
correlation, $P$ value) & 0.34 & $(1.863)$ \\
Sargan test & 0.99 & 0.63 \\
$H^{*}$ (inflection point) & 7.68 & 0.98 \\
Number of observations & 77 & 7.26 \\
\hline Source estmated & & 220 \\
& &
\end{tabular}

Source: estimated by the authors.

* Indicates level of significance of $1 \%$; ** indicates level of significance of $5 \%$; $* * *$ indicates level of significance of under $10 \%$, ns: nonsignificant. Robust

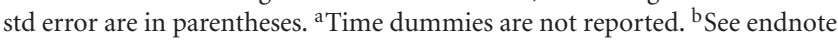
number 12.

(1) states from Southeast and South Regions; (2) other Brazilian states.

this maximum point of approximately seven years would be justified to bolster the export of more value added, technologically sophisticated products.

Arbache and De Negri [30] estimated the impact of the educational level of export firm workers on the likelihood that their firms would indeed export and found that the likelihood increases monotonically as the workers average educational level rises to that of finishing high school and a bit more. Using a qualitative model, they calculated a point of educational inflection that was higher than this paper arrived at. This disparity is likely due to methodological differences between the two studies and their use of a database that directly refers to the skill of the workers employed by exporting firms while our study uses the general average educational level of the employed share of the economically active population. We use this data because it includes workers that provide support services to the export sector, that is, public sector and transportation sector workers.

The results shown in regressions (3), (5) and (6) in Table 4 are in line those arrived at by Contractor and Mudambi [11] when they estimated the importance of human capital to the export of goods and services. They examined 25 countries and found that the human capital/export relationship is not linear, with the positive correlation only existing up to a certain point. 
The value of workforce education to the Brazilian export sector's international competitive position is reinforced by our study's results. Our confirmation of an educational inflection point can be used to support government attempts to raise the educational level of the less educated Brazilian export worker up to that inflection point, especially if improving Brazil's international competitive position is a State priority. Additionally, the study's finding indicate that Brazil's central government policy makers would be well served if they looked beyond a "one size fits all" program given the Brazilian states (or regions) marked heterogeneity when developing policies to bring about educational advancement.

Figure 1 shows the average level of formal education, or human capital level, of the Brazilian states' workforces relative to the educational inflection point ( $H^{*}$ or 6.70 years) found through our study. The average human capital level in about $45 \%$ of the Brazilian states is below this inflection point; therefore, improving the level of education in these states would generate positive marginal returns. It is worth pointing out that these states are concentrated in Brazil's north and northeast.

Over the period addressed by this study, the level of workers' education progressed least in the North, increasing only 1.12 years, while the exportation growth rate ${ }^{13}$ in this region was the second highest of all regions. The centralwest region (not including the Federal District) and the northeast region showed the greatest rises in average years of education over the study period. The Central-West's exportation growth rate was the highest among the Brazilian regions.

\section{Final Considerations}

Our study applies a model to evaluate the importance of the "fixed effects" found in each of the 26 Brazilian states plus the Federal District on exportation growth. The model's main feature is to appraise the role played by state workforce educational levels in the growth of exportation over the study period: 1995 thru 2006.

The regressions with panel data showed evidence of an exportation pattern at the state level that was based on the endowment of factors, as implied in the theoretical model presented; however, the relationship between human capital and exportation proved to be nonlinear, suggesting an inverted U shape curve. Our selected regression shows, for a workforce average of up to 6.70 years of formal education, the marginal effect of the human capital variable on exportation growth is found to be positive; but this variable's marginal effect may become negative as the workforce's average educational level increases beyond this point. Other regressions presented in the paper show this inflection point is around 7 years of formal education, what appears relatively short when compared with workforce educational levels in more developed countries. This result is probably appropriate for the production of Brazil's basket of exports goods, which is heavily weighted toward commodities (agricultural, agroindustrial, and mineral products).

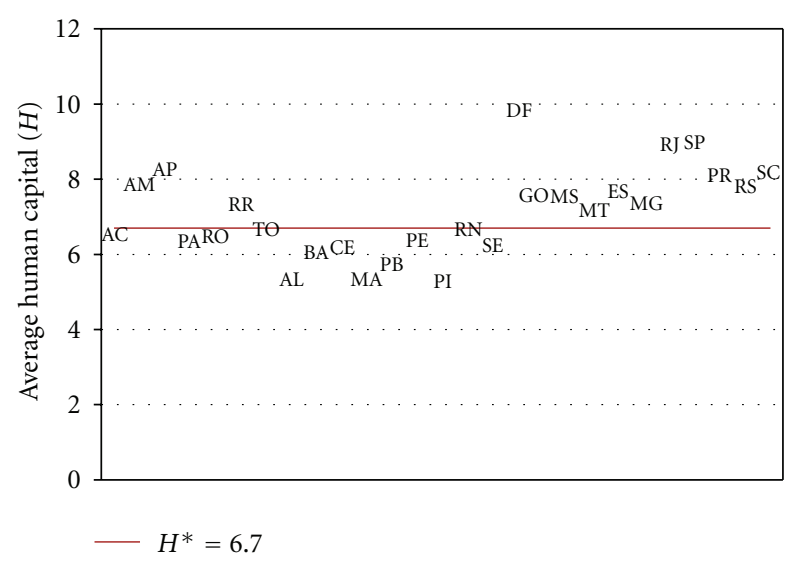

FIgURE 1: Average years of formal education in the Brazilian states (2006) Source: research data. AC: state of Acre, AM: state of Amazonas, AP: state of Amapá, PA: state of Pará, RO: state of Rondônia, RR: state of Roraima, TO: state of Tocantins, AL: state of Alagoas, BA: state of Bahia, CE: state of Ceara, MA: state of Maranhão, PB: state of Paraíba, PE: state of Pernambuco, PI: state of Piauí, RN: state of Rio Grande do Norte, SE: state of Sergipe, DF: Distrito Federal, GO: state of Goiás, MS: state of Mato Grosso do Sul, MT: state of Mato Grosso, ES: state of Espírito Santo, MG: state of Minas Gerais, RJ: state of Rio de Janeiro, SP: state of Sao Paulo, PR: state of Parana, RS: state of Rio Grande do Sul, and SC: state of Santa Catarina.

Considering that human capital is an important factor in the cost effective production of Brazilian export goods, our general recommendation is that policies to increase exportation should include programs that ensure Brazilian workers have no less than 6.7 years of formal education, even though the relationship between exports and human capital is nonlinear. As Brazilian governments, both national and state, pursue comparative advantage in the export of more technologically advanced manufactured goods, they should consider increase the years of formal education far way from 7 years.

\section{Appendix}

See Table 5.

\section{Acknowledgments}

The authors are grateful to São Paulo Research Foundation (FAPESP) for its financial support. They thank the comments from anonymous referee and the editor. All usual disclaimers apply.

\section{Endnotes}

1. In 2006, the volume of exports added to Brazilian imports (in thousands of dollars) was 2.8 times higher than the value of the same variable in 1995 (according to information collected from Institute for Applied Economic Research, IPEADATA in Portuguese). 
2. Silva and Hidalgo [31] present the recent changes in the structure of the Brazilian export sector.

3. See Woodland [32] for a complete presentation of the derivations of the direct and indirect utility functions of trade.

4. See Feenstra [33].

5. Equations (8) thru (11) assume the immobility of production factor among countries and the same hypothesis can be held in relation to the Brazilian regions because: (1st) there are cultural and geographic regional aspects that restrain $L$ and $H$ (especially the second one) mobility among Brazilian regions; (2nd). Natural resources (included into $K$ ) and sunk costs in capital investments also difficult mobility of capital $(K)$ among Brazilian regions.

6. There is a strong positive correlation that has been found between investment (gross formation of physical capital) and the industrial consumption of electricity that justifies using industrial consumption of energy as a proxy of capital.

7. Tocantins is a relatively new state, having been created in 1988, which partly accounts for this performance in exports, since the state is rapidly expanding, especially in farming and livestock.

8. The non-linear relationship with human capital is inspired in the arguments of Krueger and Lindahl [34].

9. According to Wooldridge [25], the FGLS procedure can be adapted for estimations through the serial correlation and heteroskedasticity.

10. The dynamic GMM (System) was presented by Arellano and Bover [35] and Blundell and Bond [36].

11. The consistency of the GMM estimator requires lack of second order serial correlation in the dynamic estimates, and the tests for this are presented with the results. Overall instrumental validity is also examined using a Sargan test for over-identifying restrictions.

12. From (7) in Table 4, we have: $\ln x=0,7637921 h-$ $0,0569791 h^{2}$, which calculating the partial derivative and equating to zero: $\partial \ln x / \partial h=0.7637921-$ $0.1139582 h=0 \Rightarrow h^{*}=0.7637921 / 0.1139582 h=6.70$.

13. The growth rates were calculated using the following procedure: $\ln Z=\alpha+\beta t+u$, where the growth rate $(r \%)$ of the variable $Z$ (region $i$ ) is equal to: $r=\left(e^{\beta}-1\right) \times 100$.

\section{References}

[1] A. S. Courakis, "Labour skills and human capital in the explanation of trade patterns," Oxford Economic Papers, vol. 43, no. 3, pp. 443-462, 1991.

[2] K. E. Maskus, C. D. Sveikauskas, and A. Webster, "The composition of the human capital stock and its relation to international trade: evidence from the US and Britain," Weltwirtschaftliches Archiv, vol. 130, no. 1, pp. 50-76, 1994.

[3] F. Cörvers and A. De Grip, "Explaining trade in industrialized countries by country-specific human capital endowments," Economic Modelling, vol. 14, no. 3, pp. 395-416, 1997.
[4] A. L. Owen, "International trade and the accumulation of human capital," Southern Economic Journal, vol. 66, no. 1, pp. 61-81, 1999.

[5] Y. Chuang, "Human capital, exports, and economic growth: a causality analysis for Taiwan, 1952-1995," Review of International Economics, vol. 8, no. 4, pp. 712-720, 2000.

[6] A. Rodríguez-Clare, "Costa Rica’s development strategy based on human capital and technology: how it got there, the impact of Intel and lessons for other countries," Journal of Human Development and Capabilities, vol. 2, no. 2, pp. 311-324, 2001.

[7] B. Hasnat, "The impact of core labour standards on exports," International Business Review, vol. 11, no. 5, pp. 563-575, 2002.

[8] G. M. Grossman, "The distribution of talent and the pattern and consequences of international trade," Journal of Political Economy, vol. 112, no. 1, pp. 209-239, 2004.

[9] E. L. Brooks, "Why don't firms export more? Product quality and Colombian plants," Journal of Development Economics, vol. 80, no. 1, pp. 160-178, 2006.

[10] S. Bougheas and R. Riezman, "Trade and the distribution of human capital," Journal of International Economics, vol. 73, no. 2, pp. 421-433, 2007.

[11] F. J. Contractor and S. M. Mudambi, "The influence of human capital investment on the exports of services and goods: an analysis of the top 25 services outsourcing countries," Management International Review, vol. 48, no. 4, pp. 433-445, 2008.

[12] J. B. Jensen, "Trade in high-tech services," Journal of Industry, Competition and Trade, vol. 8, no. 3-4, pp. 181-197, 2008.

[13] M. E. Waugh, "Human capital, product quality, and bilateral trade," Mimeo, Federal Reserve Bank of Minneapolis, http://homepages.nyu.edu/ mw134/uploads/56836/PQHC _v4.pdf, 2008.

[14] A. Arora and S. Bagde, "Human capital and the Indian software industry," NBER Working Paper Series 16167, National Bureau of Economic Research, Cambridge, Mass, USA, 2010.

[15] I. Brambilla, D. Lederman, and G. Porto, "Exports, export destinations, and skillsno," NBER Working Paper Series 15995, National Bureau of Economic Research, Cambridge, Mass, USA, 2010.

[16] C. Lee and Y. Wang, "A new explanation of heterogeneous human capital and trade," International Journal of Economics and Finance, vol. 4, no. 8, pp. 93-98, 2012.

[17] A. Dixit and A. Woodland, "The relationship between factor endowments and commodity trade," Journal of International Economics, vol. 13, no. 3-4, pp. 201-214, 1982.

[18] Brazilian Ministry of Development, Industry and Foreign Trade Estatísticas de Comércio Exterior, http://www.desenvolvimento.gov.br/sitio/interna/interna.php?area $=5 \&$ menu $=$ 1078\&refr=1076, 2009.

[19] Brazilian Institute for Applied Economic Research. "IPEADATA", http://www.ipeadata.gov.br/, 2009.

[20] Brazilian Ministry of Mining and Energy, Boletins Anuais de Consolidação do Mercado de Energia Elétrica e da Economia, http://www.epe.gov.br/mercado/Paginas/Mercado_9.aspx? CategoriaID=, 2009.

[21] Brazilian Institute of Geography and Statistics (IBGE), Pesquisa Nacional por Amostra de Domicílio (PNAD), http://www.ibge.gov.br/, 2009.

[22] B. H. Baltagi, Econometric Analysis of Panel Data, Jhon Willey \& Sons, New York, NY, USA, 2005.

[23] J. A. Hausman, "Specification tests in econometrics," Econometrica, vol. 46, no. 6, pp. 1251-1272, 1978. 
[24] T. Breusch and A. Pagan, "The LM test and its applications to model specification in econometrics," Review of Economic Studies, vol. 47, no. 1, pp. 239-225, 1980.

[25] J. Wooldridge, Econometric Analysis of Cross Section and Panel Data, MIT Press, Cambridge, UK, 2002.

[26] D. M. Drukker, "Testing for serial correlation in linear paneldata models," Stata Journal, vol. 3, no. 2, pp. 168-177, 2003.

[27] W. H. Greene, Econometric Analysis, Prentice Hall, Upper Saddle River, NJ, USA, 5th edition, 2003.

[28] B. H. Baltagi and Q. Li, "Testing AR(1) against MA(1) disturbances in an error component model," Journal of Econometrics, vol. 68, no. 1, pp. 133-151, 1995.

[29] B. H. Baltagi, P. O. Demetriades, and S. H. Law, "Financial development and openness: evidence from panel data," Journal of Development Economics, vol. 89, no. 2, pp. 285-296, 2009.

[30] J. S. Arbache and J. A. De Negri, "The determinants of brazilian manufacturing exports," Working Paper Series CBS42, Oxford University, Oxford, UK, 2003.

[31] J. L. M. Silva and A. B. Hidalgo, "Composição e diversificação do setor exportador brasileiro: uma analise do perfil das exportações," in VII Encontro Nacional da Associação Brasileira de Estudos Regionais e Urbanos, ABER, São Paulo, Brazil, 2009.

[32] A. Woodland, "Direct and indirect trade utility functions," Review of Economics Studies, vol. 47, no. 5, pp. 907-926, 1980.

[33] R. C. Feenstra, Advanced International Trade: Theory and Evidence, Princeton University Press, Princeton, NJ, USA, 2003.

[34] A. B. Krueger and M. Lindahl, "Education for growth: why and for whom?" Journal of Economic Literature, vol. 39, no. 4, pp. 1101-1136, 2001.

[35] M. Arellano and O. Bover, "Another look at the instrumental variable estimation of error-components models," Journal of Econometrics, vol. 68, no. 1, pp. 29-51, 1995.

[36] R. Blundell and S. Bond, "Initial conditions and moment restrictions in dynamic panel data models," Journal of Econometrics, vol. 87, no. 1, pp. 115-143, 1998. 


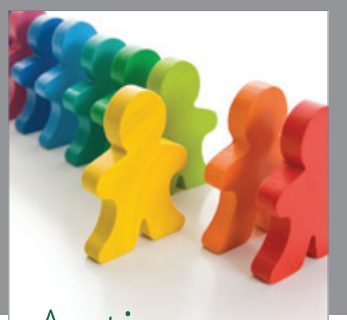

Autism

Research and Treatment
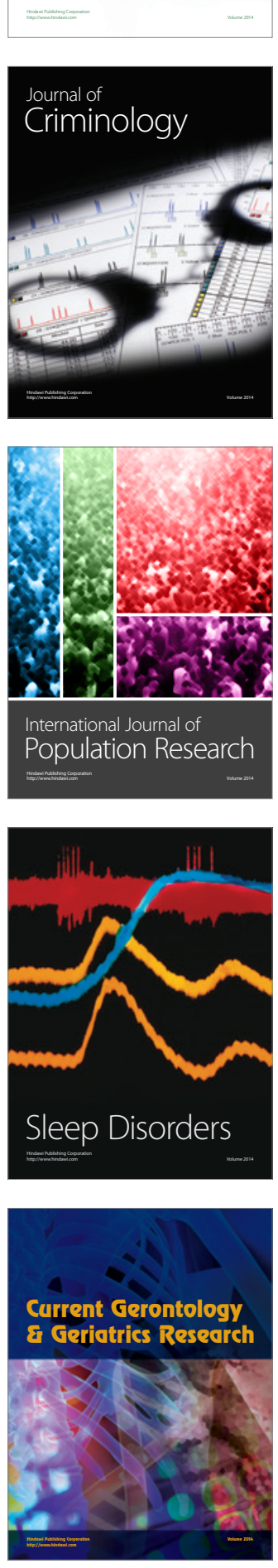
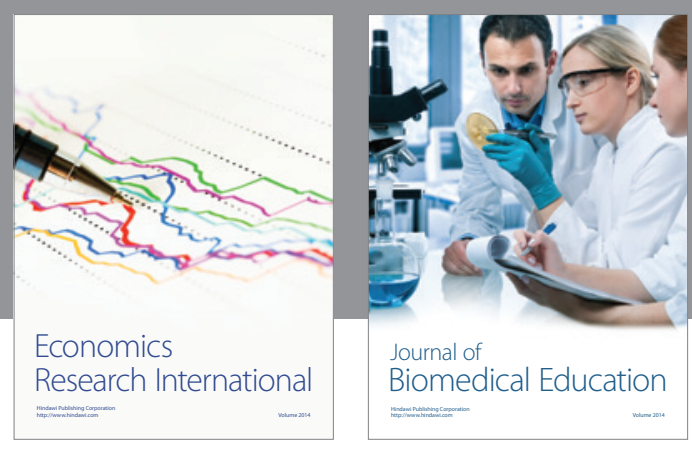

Journal of

Biomedical Education

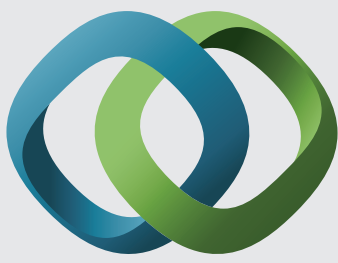

\section{Hindawi}

Submit your manuscripts at

http://www.hindawi.com
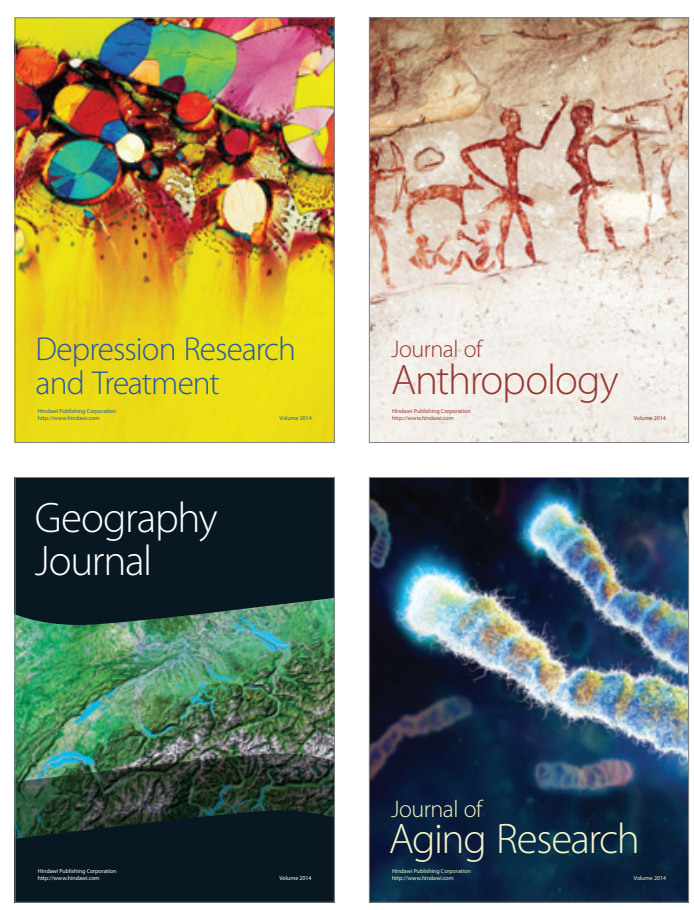

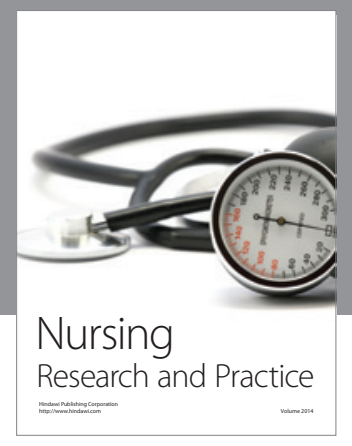

Nursing

Research and Practice

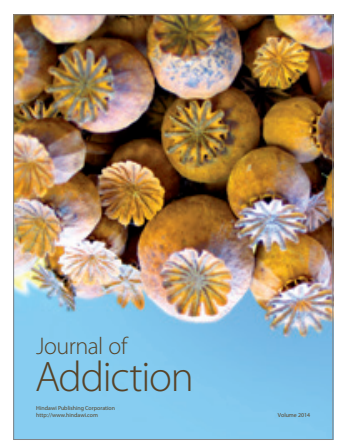

Child Development

Research

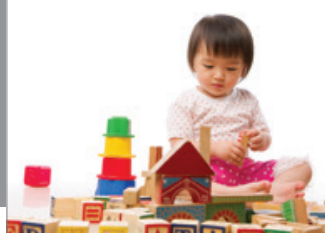

迥
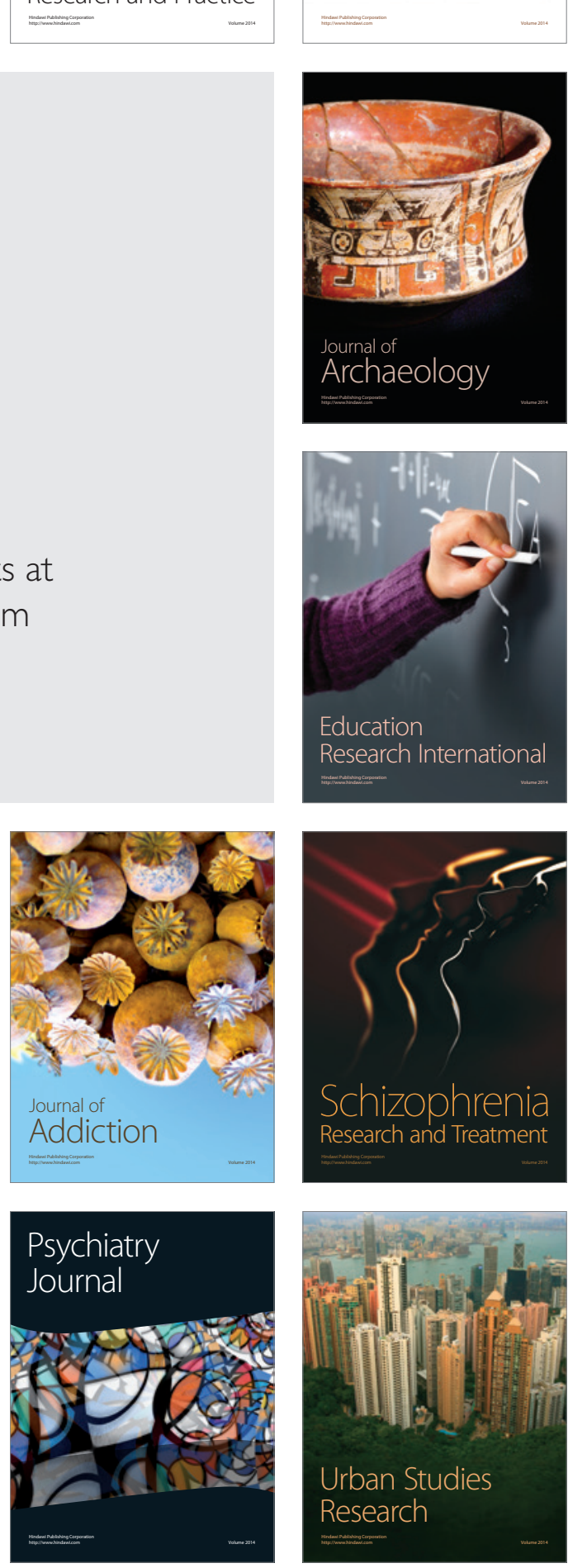